\title{
Long-Lasting Solutions to the Problem of Migration in Europe
}

\author{
J. Martín Ramírez
}

\section{Outline}

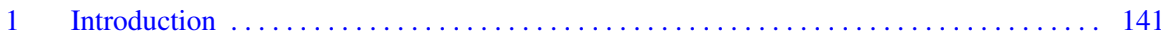

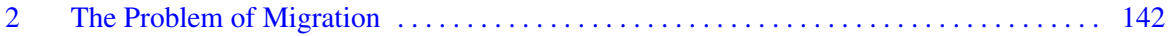

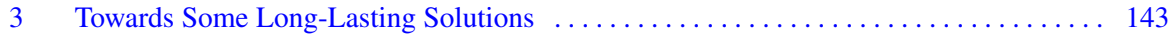

$3.1 \quad$ Going to the Roots in the Countries of Origin $\ldots \ldots \ldots \ldots \ldots \ldots \ldots \ldots \ldots \ldots$

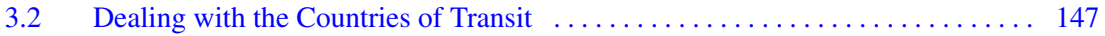

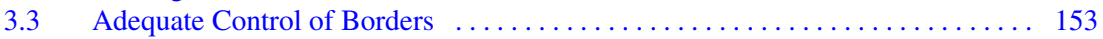

$3.4 \quad$ Measures in the Countries of Destination . . . . . . . . . . . . . . . . . . . . . 159

References ................................................... 162

\begin{abstract}
This is the following of a previous publication on the refugee crisis in Europe and its security challenges. Here we suggest some long-lasting solutions to the problem of migration. These may be summarize in four points: dealing with the countries of origin and of transit, adequate control of borders, and positive measures to facilitate the integration of the newcomers in their countries of destination.
\end{abstract}

Keywords Migration - Traffickers · Control of borders · Integration · Security

\section{Introduction}

In a previous publication on the refugee crisis in Europe and its security challenges, I concluded that a global problem like this one could not be solved without an adequate orderly, and controlled immigration policy, creating systematic and controlled arrival and integration programs, because the mental structure of European societies is not

In: A Shift in the Security Paradigm-Global Challenges: is Europe ready to meet them? Edited by J. Martín Ramírez, and Jerzy Biziewski. @ 2020 Springer International. Submitted: 27 June 2019; accepted: 8 January, 2020.

J. M. Ramírez (凶)

Nebrija-Santander Chair on Risk and Conflict Management, Nebrija University, Madrid, Spain

e-mail:mramirez@ucm.es

(C) The Editor(s) (if applicable) and The Author(s), under exclusive license 
prepared to face a disorderly increase in migration flows (Ramirez 2017, 2019). It is thus vital to regulate the arrival of migrants if we want to achieve their real integration in our culture (Espaliú Berdud 2019).

Here I will try to go forward, pinpointing the terrible damage made by the massive escape of young people from countries that desperately need them in their struggle for development; their great problem is precisely the continuous loss of human capital. Besides of that, who emigrate are not the "poor among the poor", but people with certain economic means to be able to afford the trip and contacts in the place they are going to. What is more important, according to me, is to argue that the best way would be to encourage migrants to stay home, preventing massive uncontrolled displacements, is addressing the factors that drive emigration of their own origin countries. To stop unwanted migration, the developed countries must promote a profound democratic and economic stabilization and development. We must always remember that the first right of every human being -after the right to live- is the right not to emigrate and to have the opportunity of living peacefully and prospering in our own home, as Pope Pius XII wrote in the Apostolic Constitution Exsul Familia: "All men have the right to a family living space in their place of origin". The right to emigrate is only subsidiary to the main right to have a family living space in the place of origin, when this cannot be assured.

\section{The Problem of Migration}

Migration has been a sensitive and contentious topic for ages. Escaping violence, war, poverty and environmental disasters, more people than ever are migrating worldwide. Since it is not a cyclical, but a structural phenomenon, which means that whatever the method put forward migration cannot be stopped. Currently, according to the UNO estimates, 258 million people live outside their country of birth (3.4\% of the world's population). In 1970, about $2 \%$ of the world's 3.7 billion people lived abroad (UNHCR 2017). This figure grows due to inequality, climate change, conflicts, and the interconnectivity that facilitates the movement of people. ${ }^{1}$

Migration itself affects values, identities, cultures, assimilation capacities of societies, and, far from being a problem in se, it may be a solution to many problems; e.g., benefits the demographic catastrophe present in the aging Western societies. But it doesn't always engender positive changes; it may also show important disadvantages. This is why immigration must be orderly, capable of duly regulating the massive arrival of people; otherwise our social protection systems will not resist. The illegal immigration requires proper vetting to identify criminals and terrorists- the crime rates of the foreign immigrant population are significantly higher than those

\footnotetext{
${ }^{1}$ According to the Border and Coast Guard FRONTEX 2018 risk report, only $16 \%$ of the immigrants to Europe in 2017 came as refugees from war and conflicts zones where their lives were endangered, whereas $45 \%$ confessed to have done it because of economic reasons.
} 
of the natives-, and sometimes, to put in metaphorical terms, surgical excision procedure without anesthesia will frequently induce pain. No country needs a Trojan horse. But we will leave this so interesting aspect for another parliament.

Although mass emigration to developed countries is a global phenomenon -it happens even within each country, internally displacing for instance from rural areas to urban ones: China is a clear example-, the present chapter will be focused mainly on what would be the better long-lasting solutions to its present situation in Europe, one of the leading destinations in the world in terms of migratory flows, with 77 million migrants, Russia included, according to the UN's Department for Population. ${ }^{2}$

\section{Towards Some Long-Lasting Solutions}

Immigration is an irresolvable problem at short-term. Migration policies should follow a long-term vision, addressing economic, security and sociological points of view (De la Cámara 2019), creating systematic and controlled arrival and integration programs of security, trade, development and employment issues. But, being a global problem, migration will only be solved as a consequence of a frank and sincere joint co-responsibility between all countries of origin, transit and destination, sharing the burden of dealing with both regular and irregular migration whenever possible.

This was the intention of the UN Global Compact for Safe, Orderly and Regular Migration, signed at the end of 2018 by 165 representatives of the 193 countries of the United Nations (UNO) met in Marraquesh, in a non-mandatory and rather controversial document that says, in an indirect manner, that for the entry to be safe, orderly and regular, the conditions of entry must be safe and not subject to the mercy of smugglers, seekers' and workers' entry profiles should be differentiated, and entries should be legal. Its 23 "objectives" were peppered with vague declarations, platitudes and split differences, such as the fight against the mafias that deal with human beings, the defence of the rights of immigrant workers or a change in narrative about migration towards a more positive approach. Partly in the spirit of other global agreements like the Paris climate deal, it encouraged states to co-operate on tricky cross-border matters without forcing them to do anything, and urged governments to treat migrants properly, but also to work together on sending them home when necessary. At least, it may help build the trust between "sending" and "receiving" countries that is the foundation of any meaningful international migration policy (Economist 2018).

Let us offer some recommending ways of improving migration at four different levels: going to the roots in the countries of origin, dealing with the countries of transit, having an adequate control of borders, and suggesting some measures in the countries of destination.

\footnotetext{
${ }^{2}$ intra-European migrations have increased significantly, whilst the southern shores of the Mediterranean contribute to the majority of extra-European migration (Maghreb, Egypt, Middle East and Turkey).
} 


\subsection{Going to the Roots in the Countries of Origin}

I have critized elsewhere (Ramirez 2019) the saving buenist attitude $^{3}$ of a migrationist maximalism that wants to open the doors, the ports, the windows and throw all the walls, in favor of a Weberian realism (the ethics of convictions versus the ethics of reason) (Leguina 2019): even if we would welcome forty or fifty million Africans a year, Africa will continue to have the same population. It would be good if they start helping Africans in their own countries and avoiding as much as possible the reasons why they want to emigrate (Ramirez 2016).

We want the potential migrants to have a better future in their countries. As Ousman Umar repeats like a mantra, "the solution is in the country of origin, not in the destination. You have to feed minds (well); if you feed the mind you are satisfying hunger for more than a hundred years" (Umar 2019). Some African prelates within the Catholic Church are calling attention to the most forgotten aspect of this debate: the terrible damage made by a massive escape of young people from countries that desperately need them in their struggle for development. In a book released recently, cardinal Robert Sarah, currently prefect of the Congregation for Divine Worship and the Discipline of the Sacraments, ${ }^{4}$ declares his personal position on immigration: "All migrants arriving in Europe are crammed, without work, without dignity. Is this what the Church wants? The Church cannot cooperate in this new form of slavery into which mass immigration has become" (Sarah 2019a, b; Indelicato 2019).

The European Union (EU), thus, has to structurally turn over economic resources for the development of Africa (and of Middle East), tackling the problems that are the main cause of migratory movements, analysing them and offering real help in their own home. Consequently, their priority has to be to invest in the countries of origin, because migration control has to be paid with money: financing, companies, information, facilitating their institutional, social, political and economic conditions in order that nobody will be obliged to leave their home, and creating sources of employment in those countries of origin. Some political party has proposed in its program that the EU should prepare a sort of "plan Marshall" for Africa, similar to the one USA did for the post-war Europe. ${ }^{5}$

\footnotetext{
${ }^{3}$ According to the Spanish Royal Academy (RAE) dictionary, buenismo is the attitude of who reduces the seriousness of conflicts, acting with excessive benevolence and tolerance. This "goodism" is a demagogy destined to hold power through emotional blackmail, quite different to a real goodness, born of charity or philanthropy (Robles, 2019).

${ }^{4}$ Cardinal Robert Sarah is a native of Guinea Guinean who grew up under a harsh Marxist dictatorship and became archbishop at the age of 34 with the task of guiding the diocese of Conacry, when still in his country there was the socialist regime of Sekou Touré. So, I think he knows what he's talking about.

${ }^{5}$ In the forties of the last century, America passed the Economic Co-operation Act, better known as the Marshall Plan, because its inspiration from a speech at Harvard University by George Marshall, America's secretary of state. The Marshall aid, aimed to revive Europe's war-ravaged economies, encouraged the Europeans to quash inflation and to narrow their deficits while eventually dismantling price controls and import barriers. These reforms had enormous benefits. Before 1948 fear of inflation and taxation prompted German farmers to feed their harvests to their cattle, rather than
} 
It is not enough with assigning cooperation funds. As De la Concha stresses (2019), a proper management of migration flows requires working as much as possible in cooperation with the countries of origin taking into account, as appropriate, the various causes of migration (economic, security, political prosecution, climate, etc.). Thus, a more ambitious measures are required, such as generating opportunities for the local population and offering fiscal incentives to the investments of European companies in those regions that seem to be condemned to diaspora. This move will also offer new markets for European products and services, as well as opening of EU markets to exports from these countries. And, what is more important, besides of contributing to the economic development of those countries, Europe has to improve their social and political quality of life, which is precisely what they try to find in Europe. Our main objective, therefore, has to be to strength the production base and the creation of jobs in the countries of origin, the provision of basic services (health, education) to the local populations, and the literacy, ensuring that students in their countries have the tools to decide their future and thus avoid the temptation to migrate to Europe, avoiding future victims (De la Cámara 2019). ${ }^{6}$ Either we offer them opportunities in their own countries, or they will come to ours looking for them Zalba (2014).

The best practical means for achieving it are probably inter-governmental agreements with the origin countries, giving them a generous economic aid. This is the stance taken by the Visegrad Group (V4) (Check Republic, Hungary, Poland, and Slovakia): instead of uncontrolled massive immigration, we have to act in their origin countries; instead of importing problems, exporting help in situ. This attitude would also be "much more inexpensive", as is honestly admitted by Juho Eerola, a Finn of the Nordic Freedom, or by the then Slovak prime minister, Peter Pellegrini, during his first visit to Brussels: "what we have to do is to invest in the countries where the problem is originated. Each euro spent in northern Africa is more efficient than 10 spent in the migrants who arrive massively to EU" (Eerola, 13 April 2018). But, there is need to build up conditions to create secure environment within the transit African countries bordering the Mediterranean Sea. The North African governments are responsible for effective and transparent governance aimed at management of emigrants flows through their territories. EU's money poured into their accounts are wasted as they do not cooperate as they can.

Another effort to stem the flow of migrants to Europe is "to save and protect the lives of migrants and refugees", motivating "operations of urgent evacuation" returning them to their origin countries through a repatriation programme that encourages those who have made it to northern Africa to go home voluntarily, rather than risk

\footnotetext{
sell it to the cities for money that might be diluted by inflation or seized by the government. Its true significance laid not in the cash it provided but in the market-friendly policies it encouraged. To receive aid, European governments had to commit to restore financial stability and to remove trade barriers.

${ }^{6}$ We have a similar problem within our own countries, migration towards big cities is up siding the living in small rural areas; we have to stop it offering them "the needed modern technology to have the best of both worlds. It is not an easy problem, but I feel a deep analysis needs to be done so we understand more of the dynamics behind the movements"! (Lindhard, 2018).
} 
a rickety boat across the Mediterranean. This is what UNO, EU and African Union (AU) jointly agreed in Abiyan (29 Nov. 2017): people who turn back get a free flight - cutting out the need for a perilous return journey across the Sahara. The programme has repatriated some 15,000 migrants to various west African countries, which barely scratches the surface because it reckons there are about $1 \mathrm{~m}$ of them in the African shores, waiting for their risky jump to Europe (Economist 2018).

The Spanish government did this unilaterally in 2006, after 39.000 immigrants arrived to the Canary Islands in open boats, known as cayucos: some direct forms of operative cooperation with those countries through which migrants come or transit, sending there some specific police units for working jointly with the local security forces with the aim of restraining subsequent invasions from other Western African countries.

Since the devolution of immigrants to their origin countries is one of the best deterrent action to avoid the "calling effect", 7 governments have to launch adequate information campaigns in their own origin countries to discourage potential migrants.

The EU member states are Africa's largest donors, supplying more than half the aid the continent receives. Africa exported twice the value of goods to the EU as it did to China in 2017.

But it is not just a matter of addressing the factors that drive emigration. Europe and Africa share something much more fundamental: a future dependent on one another. As Moroccan King Mohammed VI pointed out in 2017, solidarity between Europe and Africa has to be "built on shared responsibility and mutual dependence." The European continent is a global player worthy of genuine partnership of equals with Africa that priorities concerning mutual interests through rapid funding in education, health and infrastructure for Africa's youth would contribute to global growth. Europe's investment must be bolder in terms of financing, policy and governance reforms than what is currently on the table (Cole 2019). Economic development, government reforms, institutional strengthening, will result in common prosperity. Europe, poor in natural resources and in demographic decline, desperately needs to contribute to the unblocking of the future of Africa. Up to now, the -economically important- European efforts have to qualify as at least disappointing. The EU needs to encourage, promote opportunities in Africa, move from a policy built around aid to cement our relationships on trade and investment (Palacio 2019a).

Cooperation between states that produce migrants and those that receive them can help to streamline migration flows. The European Union has to structurally turn over resources for the development of Africa and Middle East, which are the main source of migrants nowadays, through agreements with extra communitarian countries for stopping irregular immigration towards Europe. And this requires patience and diplomacy, treating the partner governments as equals.

\footnotetext{
${ }^{7}$ As an anecdotic comment, this is precisely the etymologic root of Venice, Venezia = veniunt etiam $=$ they (the fugitives from other places) kept coming.
} 


\subsection{Dealing with the Countries of Transit}

The optimism of the "refugees welcome" campaign in 2015-Wir schaffen esled towards an uncontrolled flood of refugees which destroyed the perception of order and stability. In June 2018, there was a great turn in the attitudes of the rulers regarding immigration, with a broad consensus at the European Council around much more restrictive. This practical agreement intended to hand over the decision-making capacity over who enters and who does not in the "Fortress Europe", strengthening the policies of controlling the external borders; fighting against traffickers; and more aid in the countries of origin instead of endless aid in Europe. There is a need to strengthen collaboration with transit countries.

\subsubsection{Strengthening the Control of the External Borders}

It is necessary to prevent ships from leaving their points of origin. In cases where this is not possible, the practice should be implemented that those rescued at sea should be assisted and returned to the point of origin or departure of navigation. This is the specific task of Frontex, the European Border and Coast Guard Agency: provide technical assistance and support to the countries of origin and transit to help strengthen border controls, even if it cannot replace national competence; it is converted into an authentic border police, but not in charge of rescuing. I will to come back to this point later.

\subsubsection{Fighting Against Traffickers}

According to the NGO African Center for Strategic Studies, there is a migratory flows that move 3.5 million people from one place to another from and within Africa in the hands of traffickers; $50 \%$ of them are minors, and only $1 \%$ of those 3.5 million, will try to reach Europe; the remaining 99\% travel between African countries. ${ }^{8}$ In this context, I point out at a report by the Department for Human Rights at the $\mathrm{UN}$, marking the horror of criminal smuggling networks which lead to humanitarian scandals such as: enslavement; imprisonment; rape; prostitution; the sale of organs; and camps, whose living conditions are beyond imagination.

What alternative do citizens of many African countries have to come to Europe? If the European states renounce their ethical convictions, delegating their responsibility, mafias and some connected "heroic" NGOs will occupy the scene doing the dirty work. Those still determined to reach Europe may have to pay large sums to people-trafficking gangs and risk their lives in the sea (we may say the same about

\footnotetext{
${ }^{8}$ F.inst. there are many refugees in the Lake Chad region, intersection of four countries of the Sahel, as, (Alupo et al. 2019); and a huge wave of immigrants towards South Africa or other rich countries, blamed by locals for supposedly taking jobs from locals, committing crimes, or the spread of infectious diseases.
} 
America, substituting the word "sea" by "desert"). The more borders, bureaucratic obstacles, closed routes and prohibitions the immigrant finds, the more profitable for the trafficker. No one moves as many people on the planet as immigration traffickers, nobody determines human flows as much as their implementation in a given territory, nobody has their flexibility to change plans and adapt to changing circumstances and nobody gets so many benefits as they do. Their criminal business is more lucrative nowadays than drug or arms trafficking.

Some of those traffickers have changed tactics. Before, they put hundreds of immigrants in old overloaded wooden boats with the aim of trying to reach Europe. Nowadays, after cashing from them, the immigrants are taken in safe boats from African territorial waters, until they know that the ship of some NGO is a few miles away. Then, once in international waters, they put on life jackets, crammed them in zodiacs, which can barely sail a few hours and warn by radio that there are shipwrecked people in the area. The more rescue boats they have, the more immigrants will try to cross the Mediterranean..., and the more deaths, drowning in the sea, those claimed heroes of the goodism will provoke. A NGO director denounced on television that although he had managed to rescue 60 people from a zodiac, another 340 had perished. What nobody asked was if he did not realize that by telling those who leave Libya that there are boats a few miles away they are contributing to the death of hundreds of people who, for one reason or another, cannot be picked up. ${ }^{9}$

Trafficking in human beings to the European destination is more profitable than drug trafficking: it moves around the Mediterranean, according to the latest UN report published last year, about 7 billion dollars. Just take the account: boats for 30 people are used for 120, crammed, standing, and almost unable to move for hours. At 4,000 $€$ per head, ${ }^{10}$ it gives $480,000 €$ per trip. It is paid in two parts: the first $2,000 €$ to take them from their country of origin to the ports of Libya and the other 2,000 to move them to European port, in an offshore mothership, and then in small boats that launch into the sea in a point located by GPS where they can be picked up by the rescue boats of the NGOs, or by merchants, fishing or recreational. If they do not find this type of boats in the area, they make a distress call with a satellite telephone with the coordinates. If the trip is frustrated and they are returned to their countries, they try again when they have collected the money. And several thousand have not even had that opportunity because they have lost their lives. With that turnover, there is no problem in paying the corresponding bribes in each place (Fernández Arribas 2019).

"The good trafficker tries not to lose the immigrants who have been his clients. His goal is to get them to Europe and earn money. If they lose, e.g., a truck with 40 immigrants between Agadez and Algeria or a boat that sinks with 100 people, is not a problem, because they have already paid; but if they lose $500 \mathrm{~kg}$ of cocaine or two

\footnotetext{
${ }^{9}$ The reception in several European countries of migrants collected by NGO ships reinforce the effectiveness of the mafias that can sell their services in the market to attract new customers they will charge plus.

${ }^{10}$ This price depends on the time of the year, the state of the sea, and the amount of bribes the mafias have to face, paying to local authorities, even with Coast Guard or as in Niger, with the Army.
} 
boxes of Kalashnikov, then they do have a serious problem. That is the difference". And how are these people's traffickers? "These gangsters are criminal entrepreneurs, but entrepreneurs. They must have many contacts, be credible, creative, charismatic, with the power of conviction, knowledge of the routes, the laws, the latest news... which make them very fast, elastic and flexible. They also participate in other businesses; f. inst., when the vehicles that bring immigrants back through the Sahara return, they never make them empty: they carry weapons or drugs back to take advantage of the trip" (Musumeci and di Nicola 2016).

Fernández Arribas (2019) offers a very detailed description of how tens of thousands of human beings are stranded in territories dominated by mafias, in their expected way towards Europe. Although every corner of the world retains its specificities, the human traffic mafias analyzed by the UN reflect some common patterns. All of them have recruitment agents from the main groups that are victims of extortion. A second level is that of the local mafias, who know the land and generally pay the collectors. One more step is that of small-scale service providers: trucks, boats and other means of transport. The most dangerous level is that of the big international mafias, who control the entire process and also add links to large international crime groups and use immigrants as a way to earn money quickly and easily. Infrastructures built for the exploitation of the mineral resources of the desert, oil in Libya and uranium in Niger, facilitate trips through the desert. According to reports from the Spanish Police, Nigeria and Libya are the most active and most established bases of immigration mafias in Central Africa, with ramifications in other countries, where Sudanese mercenaries act unscrupulously. In the waiting time, they live in abysmal conditions, suffering very serious violations of the human rights, such as abuse, harassment, violence, robbery, kidnapping, extortion, common torture and rape.

In North Africa they have their point of convergence in Agadez, a town north of Niger, or in Sehba, south of Libya, where control is exercised by heavily armed tribal groups. From that point of confluence, they are transferred to the coastal cities of the Tripolitana region, where trips are negotiated and where part of the population collaborates with their garages as a temporary shelter at an abusive but obligatory price for those who see the end of Your nightmare Construction, agriculture or any job in order to get the money. The boats used are manufactured in Libya and the fishermen always have on board some drum of gasoline, pure gold for the weak boats of the new slaves of the 21st century. In Libya, each link in the chain receives its commission, especially those who seek protection and security, from militias to corrupt authorities.

This action-paying poorer ones to set up vast holding-pens for humans in unhuman conditions- is a big business for a few behind the misery of many others, and involves something which would not be tolerated at home, but it seems somehow acceptable in these situations because it is out of sight.

Stopping these traffickers, which is the solution that many politicians in Europe offer to regulate immigration, is almost impossible; they are always ahead of a European immigration policy, without the necessary coordination. A clear example has been the failure of the military Operation EUNAVFOR MED Sophia (from 2015 to 2019), which ambitious goal of dismantling the mafias that traffic with people from 
the Libyan coasts to Europe has not been fulfilled, partially because the closing of the Italian ports to illegal immigrants has left it out of play. Due to the fact that operation SOPHIA no longer uses ships but only unmanned aerial vehicles, it cannot continue rescuing people at sea. Federica Mogherini, at that time High Representative of the Union for Foreign Affairs, explored a new mission, with more modest goals: to train the Libyan Coast Guard to control their own waters and avoid the departure of irregular immigrants; but there were also no practical results. This shows the external and humanitarian action of the EU, as it really is: "lack of criteria, commitment and agreement on immigration issues... Public opinion will continue to show ships coming from the Libyan coasts and criminal organizations will increase their profits" (de Ramón-Laca 2019; see also Espaliu 2018, Espaliú Berdud 2019).

As accurately pinpointed by Bitzewski (personal communication), though, it is not the EU administration to blame but the heads of states not being willing to take the action. They point their fingers out towards the EU but, when the EU puts proposals on the table, they get reluctant to contribute to the common effort. It starts with the frontier countries, crying but doing very little to protect their own borders, and goes to the rest of Europe raising any reason not to commit themselves to the program. The EU should be tougher on the North African governments, corrupted and ineffective. A carrot and stick should be one of the ways to start discussion with them. It's their obligation to control migrants movement within their territories but they make money on it! Turkey and Egypt are perfect examples of the game. When they want they can stop trafficking! But, obviously, the money is the main reason for action. The North African countries are interested in this business and it is up to us to give them a signal "do not be too smart". We deal with state controlled trafficking and we are very naïve not forcing these governments to take the responsibility. We can help them but we cannot work for them.

\subsubsection{Aid in the Countries of Transit, instead of endless aid in Europe}

A key move to avoid the "calling effect" is to guarantee security and economic agreements -migration control has to be paid with money-, with those countries migrants transit through in their way to Europe, preventing them from leaving its coasts and returning to their country of origin those people whose asylum in the EU has been denied.

In November 2015 the EU established the Emergency Trust Fund for Africa (EUTF for Africa) with an allocation of $€ 647.7$ million covering Algeria, Tunisia, Morocco and Egypt, aimed "to contribute to safe, secure, legal and orderly migration from, to and within the region and support an effective management of migration flows that protects human rights"

Turkey is the main starting point for the arrival of potential refugees from Middle East to Europe. There are more than 3 millions Syrian refugees, and almost another one in Lebanon. The repatriation agreement signed by Brussels and Ankara in March 2016 
-entering 6,000 million euros annually in the Turkish coffers ${ }^{11}+$ VISA free travel for some Turkish citizens- has been a quite good example of efficacy, convincing them to keep refugees from Europe's shores: more than 900,000 migrants-three fifths of the detainees came from Afghanistan and Pakistan- have been detained in Turkish territory since the document entered into force (Turkish Directorate General of Migration Management 2019). According to Gerald Knaus, leader of European Stability Initiative (ESI), the entry of refugees into Greece was reduced "by $96 \%$ and even higher in the number of deaths". And, in a more global view, the more than one million irregular migrants (mainly refugees) who arrived in Europe in 2015 have fallen to 171.635 in 2017 . Turkey thus has played a leading role as a dam to contain migration outside Europe.

In the future, EU will have to invest more in integration and public awareness programmes in Turkey. Erdogan himself has proposed resettling at least some of the refugees in a safe zone he wants set up in northern Syria. All of this is legally possible. Syrians in Turkey do not enjoy formal refugee status, which would protect them from deportation, but "temporary protection", which does not. According to the High Commissaire of United Nations for Refugees (ACNUR, in French), a Turkish meltdown would send economic shockwaves or new surges of migrants onto the European mainland. Erdogan has encouraged such fears (July 22nd, 2019), threatening the suspension of the migration deal over the EU's sanctions. ${ }^{12}$

Another point for the arrival of potential refugees from Africa is the Maghreb. Those EU southern members with close ties to it have an special interest in encouraging the reform of state structures, as well as working to reduce the socioeconomic disparities and lack of opportunities that remain the public's most pressing problems in those countries. Two successful cases have been the attempts of cooperation of the EU with Morocco and Tunisia, as well as a. very important job in the control of migratory flows and the fight against mafias, terrorism and drug trafficking is due to the creation of a Coordination Authority for the Gibraltar Strait. By way of example, there is a positive counter-terrorism cooperation carried out by several EU countries working closely with Northern Africa on security, providing training and equipment for counter-terrorism and conducting some joint operations.

Morocco might be a capable security partner as the authorities closely monitor its population and controls its religious sphere. It has been successful in preventing attacks and obtaining information that can benefit its European partners, but its counter-terrorism efforts fit within a framework of conserving rather than transforming the state's unaccountable relationship with its subjects, which relies on a repressive political system and resists outside calls for reform.

\footnotetext{
${ }^{11}$ NATO has also awarded US\$ 5 billion to Turkey.

${ }^{12}$ Four years later, just when this book is going to press, the crisis has returned. Turkey does not seem proactive anymore. Tayyip Erdogan has called for more European support for ending the war in Syria and for receiving millions of refugees. And as a pression measure, on February 28, 2020, Turkey decided to open its borders for migrants to move to the European Union. This has brought together more than 35,000 migrants along the border with Greece. Three weeks later, though, following the strategies of the other countries to avoid a further spread of COVID-19, Ankara has announced just the opposite: the closure of the EU's borders.
} 
The Spanish authorities have observed with relief a downward trend in arrivals in mid-January 2019 , with a significant reduction of a $39 \%$ of the figures of irregular immigration: the entries, an average of about 1.200 a month, confirm that the flows have been considerably reduced since then and that they have fallen to levels below those registered the previous year, when Spain became the main European gateway for irregular immigration. This proactivity of Morocco, deploying agents to reinforce the fight against the mafias, stop the exits by sea and employed its coastguard in the rescues on the high seas, has been highlighted both by Spain and by an internal report of the European Commission as the most effective tool to contain migrants. This change of attitude coincided with the announcement of the visit of King Philip VI to Rabat, which was finally held on February 13, 2019. On that trip, the Spanish monarch asked Mohamed VI to go "beyond" in the control of irregular immigration. Later, the fisheries and agriculture agreements, signed by EU and Rabat with an injection of 140 million euros to contain migratory flows, have also been key to boost Moroccan collaboration. Besides of that, Spain has approved to add the almost 60 million that Rabat asked last year to contain the exit of immigrants; that is to purchase surveillance equipment "to combat irregular immigration, immigrant trafficking and trafficking in human beings", as well as for fuel, maintenance of patrols, diets and salaries (Palacio 2019b).

The Moroccan and sub-Saharan return agreements are also praised as a "deterrent factor" to avoid the "call effect". Morocco moves many sub-Saharan people to the south, leaving them lying in the middle of the desert, or locked in small cells inside an illegal detention center in Arekmane (20 km from Melilla) and then deported to their countries.

Tunisia has also made significant advances in its security policies, but it has yet to find balanced ways to deal with its porous borders and the disproportionately large number of radicalized people.

Unfortunately, the attempts to solve the problem of migration with Libya have been rather frustrating. Libya is a too fragile state, a territory without government since a few years ago, which is key in the irregular migratory flows towards Italy and, in the late times, increasingly diverting the flow of west African migrants to Spain, via new Algerian routes (Fernández-Sebastián 2018). Nowadays it is the largest and more serious migration corridor, due to the use of mafia "facilitators", as we had previously commented. In this context, some Libyan militias behind much of the people-smuggling migrants across the Mediterranean claim that EU and, more specifically, Italy have given them money and equipment to improve the coastguard stopping migrant boats from setting sail. This may explain the falling of the number of migrants crossing the sea.

Finally, the European leaders seem delighted with the cooperation with Egypt, where immigrants no longer arrive due to the decision of this country to prevent them from leaving its coasts. If all the countries of the south did like Egypt, there would be no immigrants at sea. 
A punctual example of joint collaboration of countries of both sides of the Mediterranean Sea is the cross-border military exercise Neptune, with the strategic objectives of unifying efforts and coordinating action plans among the Mediterranean countries, ${ }^{13}$ especially in terms of detention and combating the movement of foreign terrorists through ports on both sides of the Mediterranean. Thus, passenger and freight transport vessels were included in the controls and the use of Interpol databases could be activated participation. This activity has been developed between several ports such as Tangier Med, Tangier City and Bni-Ansar (Nador).

In sum, the EU should remain committed to encouraging and supporting the most significant pressing remaining security challenges faced by those countries, such as: (1) the reduction of the social frustrations, economic inequality, lack of opportunities, and governance problems that increase the likelihood that people will join extremist groups and recruit radicalized individuals; and (2) the reform of state structures, especially in relation to: (a) improving security governance based in an adequate culture and professionalism of the security forces (f. ins., training of police officers, courts judges and staff, customs and coast guard officials); and (b) developing systematic approaches to prevent further radicalization and addressing conditions that facilitate it, such as: exploring better ways to handle radicalized individuals than large-scale incarceration; distinguishing between committed jihadists and those who are more open to reintegration into society; and developing programmes to promote religious education and awareness, gearing them towards pupils and their families from an early age, so relevant to the treatment of radicalized individuals and the prevention of further radicalization (Dworkin and El Malki 2018).

\subsection{Adequate Control of Borders}

Although the priority has to be focused on the countries of origin and transit, the fact is that we have to face a massive amount of irregular migrants who are arriving to our borders, because a chaotic, uncontrolled immigration cannot be allowed. The main objective of EU policy in this topic should be to encourage legal and orderly immigration and deter illegal flows. What should be the European criteria for who is welcome to Europe and who is not, to avoid an uncontrolled migration into our continent? How could be accomplished the aims to become a historic leap in the consolidation of a European area of freedom of movement without internal borders?

A Spanish writer, de Prada (2019), has recently reminded the clairvoyant solutions offered by Thomas Aquinas already in the Middle Age on the obligations and limits of hospitality, making clear that the help demanded by those who suffer should not be confused with their unconditional reception. He refers to several possible types of peaceful immigrant: who passes through our land in transit to another place; who comes to settle in it as an outsider; and who wants to fully join the nation that receives

\footnotetext{
${ }^{13}$ In the Neptune-2 activity, in August 2019, have participated Morocco, Algeria, Tunisia, Spain, France and Italy, together with experts from the Frontex and the World Customs Organization.
} 
it "embracing their religion" (their culture, we would say nowadays). He always puts the notion of common good, which requires a desire to integrate into the life of the host country; and he is inclined not to admit them until examining their degree of "affinity" with the nation that receives them. And, as a measure of legitimate defense, we should reject those immigrants considered hostile, understanding as such not only those who have the purpose of perpetrating crimes or violence, but in general those who harbor intentions contrary to the common good of the nation that receives them (see also: Ramirez 2019).

The decision on who is welcome and who is not does not belong to the humanitarian people, even less to the people-smugglers, but to each state. Security and protection of the borders is competence of each state member. Without borders there are no states and no one else can supplant a state's right to manage and protect them, treating migrants humanely but also firmly, swiftly returning those who arrived illegally or whose claims to asylum have failed. ${ }^{14}$

Even if the EU lacks competence over it, it does not preclude the convenience of an Europeanization of the migration management, through a joint cooperation for specific purposes, even if it means losing part of the national authority over a very sensitive area of the territory. The political leaders of the EU must improve their coordination and develop common legislation on borders and immigration, creating systematic and controlled arrival and integration programs, focused on the new scenarios, such as the solution of the migratory crisis, with a common, effective, and decisive security policy, finding a balance between the implementation of measures that guarantee the security of the states, while respecting the rights of those migrants who no longer enjoy their protection in their respective countries of origin.

The EU not only lacks competence over the management of the flow of refugees, but also lack of homogeneous response, as it is shown by of the Dublin Regulation (EU European Parliament 2013), which has resulted an absolute failure, inept to establish a coordinated strategy with minimal effectiveness. The EU foreign policy remains hopelessly underpowered, limited to coaxing national capitals towards agreement and supporting their ad hoc initiatives (The Economist Economist 2019a, b; Niño 2019). It is good to remind again that it is not EU to blame but the states not taking actions.

The Dublin Regulation (2013) determines the EU member state responsible for the examination of an application for asylum seekers of international protection under the Geneva Convention Relating to the Status of Refugees of 28 July 1951, as supplemented by the New York Protocol of 31 January 1967 (EU 2013). According to this legislation, the first member state in which the asylum application is submitted will be responsible for the examination of the request for international protection and the asylum seekers have to stay there. This, the so-called "one stop one shop", burden the countries situated at the entry to Europe, notably those in the South, and the individual preferences -that is, where people arriving into Europe actually

\footnotetext{
${ }^{14} \mathrm{We}$ have to admit, though, that this is easy to prescribe but hard to enact. It requires a lot of time and patience. Courts are overstretched, many cases are hard to allocate and poor countries may not want their citizens back.
} 
want to go to and where do they wish to live- are bound to not be properly taken into account. Consequently, if they move later to another European country -known as secondary movements-, this second receptor may return them to the first state. This secondary migration penalizes those southern countries, because most refugees arrive to the coasts just as a transit towards other northern European countries, where many of the newcomers had linguistic and cultural or family ties. or with better job opportunities and welfare provision. As a matter of fact, most of them live already in Germany. ${ }^{15}$

In front of this, the different EU Member States have rather antagonistic approaches:

(a) Northern countries, preferential asylum for most of the refugees, are in favour of a quotes policy imposed by Brussels' "eurocrats" for the reubication of refugees, ${ }^{16}$ and suggest an EU budget with more funds for those regions with higher number of asylum seekers.

(b) Mediterranean countries, plus Portugal and France, suffering a heavy migratory pressure in their borders, have the feeling of being left alone to cope with immigrants, and reject the responsibility of attending by themselves everybody who arrives to their borders, because it would mean establishing a sort of sanitarian cordon with the rest of the communitarian block. Their aim is a reform of the Dublin Regulation and the help of the other EU countries in the sharing of the irregular immigration arriving to the outer borders. For instance, the Greek government and aid agencies argue that the EU must overhaul the Dublin Regulation, so that asylum-seekers are distributed more evenly. The current system, they say, is unfair. Five countries - Greece, Italy, Spain, France, and Germanyreceived over three-quarters of Europe's asylum applications in the first half of 2018. Greece has had to deal with 70 times as many claims as Hungary, a country of comparable size and wealth. The rules are also ineffective: EU money is not an adequate replacement for relocation. Southern countries are also reluctant to expand Frontex because this affects their rights to the sovereignty of control of the territory, but also concerns related to better registration of migrants.... This is the key problem!

(c) the Visegrad countries (V4) -Poland, Hungary, Czech Republic and Slovakiaplus Baltics (Latvia and Lithuania) and some recent addings (at least, Austria, and partially Italy), call for reform, and refuse to consider any binding sharing

\footnotetext{
${ }^{15}$ In 2017, Germany received 222.560 applications, almost double that of any other EU country, requesting the return of 64.267 refugees to other EU countries, but only managed to execute $15 \%$ of the returns of asylum seekers requesting from the EU. Based on that, the German home minister, Horst Seehofer, wants to send tens of thousands of migrants to Italy, and, on the contrary, Italian home minister, feels legitimized to send those who arrive to the northern European countries; f.ins.,"France was to welcome 9,816 immigrants, but in reality accommodated only 640" (France has returned to Italy 10,949 people in 2018).

${ }^{16}$ Following the principle of solidarity, which is included in the Lisbon Treaty (2007), Jean-Claude Juncker called on the Member States of the EU to share refugee quotas according to the wealth of each country and population size, but it shattered and the European policy of immigration and asylum was marked by increased sovereignism in the States of Europe.
} 
out of asylum-seekers. ${ }^{17}$ Based on their right to security, they insist that their priorities are more about controlling Europe's outer borders, in order to preserve the free movement of persons within the Schengen space, than about managing the burden of refugees who cross them.

What should be a reasonable attitude to avoid an uncontrolled moving of illegal migrants within the Schengen area? The intended distribution of the burden of refugees imposing a quota system -i.e. every EU state had to admit a fixed amount of people- has not worked: only a $28 \%$ of the quota has been achieved by the different members. This system of quotes was firmly opposed by the Central Europe Defence Cooperation (CEDC), ${ }^{18}$ arguing that the structures of their countries are not "ready" for supporting the social weight of the newcomers: it would be highly detrimental to the national security and sovereignty. ${ }^{19}$ They felt marginalized by Angela Merkel decision to keep Germany's borders open to refugees at the peak of the crisis in 2015, without any previous consultation; it seemed to them, the chancellor had turned them into transit corridors for undesirable migrants drawn by the promise of a cushy life there.

They suggest as alternative to accept the free choice of country. Following this rationale, the Polish minister of Foreign Affairs in years 2015-2018, Witold Waszczykowski, was backing the disagreement of his president, Andrzej Duda, to force the entrance of immigrants against the wishes of the Polish people, asserts that "the security of Poland is more important than the unjustified decisions of the European institutions on the issue of the refugees". Viktor Orban even dares to declare Central Europe a "migrant-free zone".

The Central European countries are pushing for the EU to get involved in the custody of the external borders and accuse the southern countries of letting irregular migrants pass unchecked through their territory to the rest of the EU, and ending up circulating in Europe at will. For instance, Sebastian Kurz, at that time Austrian Kanzler and rotatory President of the Council of the EU, told in a local newspaper "I am afraid that many are trying to avoid the high number of migrant records that they would have to do" (referred in $A B C, 9 / 9,2018$ ). His words suggested that national authorities sometimes turn a blind eye to not registering migrants and that, on the

\footnotetext{
${ }^{17}$ In a French interview, the African cardinal Sarah declares to support the countries of the V4: "These countries do well to want to maintain their identity: globalization becomes a medical prescription mandatory. The mondo-patria (homeland world) is like a liquid continuum, a space without identity, a land without history".

${ }^{18} \mathrm{CEDC}$ groups seven Central European countries: the four integrating the V4 plus another three ones (Austria, Croatia, and Slovenia).

${ }^{19}$ Based on this assertion, Slovakia has contested the extraordinary measures adopted by Decision 2015/1601 of the EU Court of Justice on the application of a system of quotes in the reubication of refugees, mandatory for all the members, based on the argument that "it is inappropriate, because it would destroy the social coexistence and the democracy, and unnecessary for the achievement of the pursued goal". For example, an uncontrolled acceptance of any asylum seeker would be a danger for the needed social cohesion or the hosting countries and, what is even worse, the infiltration of terrorists among the refugees would be a serious risk for the security in the European space (Eslovaquia y la reubicación de Refugiados, 2017).
} 
other hand, a community official who did not work directly for any state would not allow those distractions.

The EU summit in Brussels on June 28th 2018, following a suggestion of Angela Merkel and Horst Seehofer, reached a transitory agreement based in two points: (a) bilateral agreements between different states, stopping secondary movements in their inner borders, i.e. sending the refugees back to the state in which their asylum application was first submitted, obviously with an economical compensation; and (b) more resources for setting up centres of transit (internment) or "landing regional platforms" with the task of reviewing asylum applications, "distinguishing between economic migrants and those needed of international protection". This move would speed up the deportations, disincentives dangerous adventures and reduce drownings at sea.

This seems to partially accept Sebastian Kurz's proposal of a "Copernican revolution" in asylum policy migratory model, as a new possible alternative similar to the one applied in Australia: to implement the number of naval patrols for intercepting boats with refugees and confine them in islands like Nauru o Papua-New Guinea": control first; then generosity. Following this model means two things: First, taking tough action along borders, at sea and "upstream" (inside Africa) to slash the number of asylum-seekers smuggled to Europe; thwarting smuggling, the argument goes, would reduce drownings at sea, and reassure voters who might otherwise be tempted by the far right. Second, striking deals with poorer countries to establish camps, run with UN agencies, to receive, detain and, eventually, return migrants.

It is a laudable but ill-defined goal, because it is unclear where to establish those camps. It was mentioned "in safe countries outside the EU". But where? Some members want deals with North African countries to reduce departures, ${ }^{20}$ but it still unknown which non-European countries would be willing or able to host such centres. $^{21}$ In front of this North African rejection, the Danish prime minister at that time, Lars Lokke Rasmussen, revealed that some communitarian countries are

\footnotetext{
${ }^{20}$ Austria, which occupied the EU presidency that semester, hoped for a quick agreement to equip Frontex with a supranational force of up to 10,000 members and to establish a landing platform for irregular migrants in North Africa.

${ }^{21}$ ALGERIA: Just the day after the summit, Algerian Foreign Minister Abdelkader Messahel said in an interview with the French broadcaster RFI: "I believe that Europeans have enough capacity, means and imagination to manage these situations." "It is excluded that Algeria opens any retention zone. "MOROCCO: the next day, the Moroccan Foreign Minister, Naser Burita, emphatically stressed that this country has always "rejected and rejected" in its territory the detention centers for foreign migrants. TUNISIA: For logistical and political reasons, it could be the ideal candidate to host this type of centers: its coasts are the closest to the maritime zone where the majority of migrants sailing from the western strip of Libya are rescued; and, its democratic transition seems to be quite consolidated, being the country in the region that receives the highest volume of EU aid funds per capita. However, the Tunisian ambassador to the EU, Tahar Cherif. abounded in categorical rejection by his political class and public opinion. "For Tunisia, the creation of reception centers is a red line," says Valentin Bonnefoy, a researcher at the Tunisian FTDES, a NGO specialized in migration. More than seven years after the revolution, this Maghreb country does not have an asylum law, something that many observers attribute to a veiled strategy to avoid becoming a host country. EGYPT also rejected the possibility, although in a not-so-sharp way: "the EU migrant reception facilities in Egypt would violate the laws and the constitution of our country," said Parliament President Ali Abdel
} 
seeking to establish camps for failed asylum-seekers in a continental country, but out of UE, more specifically in the Balkans. There is even a third possibility to consider: within the own EU border.

Jean-Claude Juncker, in his 2018 speech on the state of the EU, proposed to establish a more efficient control of the EU's external border, converting Frontex, created in 2004 and reinforced in 2016 as a European Guard of Coasts and Borders, into an authentic border police, but not in charge of rescuing. Although still subject to the control of the national authorities, it is provided with broad competences in areas such as the control of irregular migratory flows from outside the EU, the return of irregular migrants to their countries of origin, the detection of illegal steps between countries of the club and the fight against the channels of transit in third countries. On November 8th 2019, the EU decided to grow it from 1,300 s to a standing corps of 10,000 , with a $26 \%$ jump in funding next year, to $421 \mathrm{~m}$. $€$, For the first time, the EU will be able to dispatch gun-toting men and women clad in EU uniforms to patrol its fringes, without asking member-states to cough up guards. In this way, the surveillance capacity in European territory will be reinforced.

This necessary hard-headed policy of tough border controls, swift return of illegal immigrants and encouraging would-be migrants to stay home obliges governments to work with others in the control of its migratory flows. Europe cannot maintain the Schengen system of internal free migration if it does not control its external borders. And, we have to admit it, it does not. The EU has so far failed in all its attempts to establish a common policy to address the problem; it has become impossible to have a level-headed conversation about managing migration in Europe.

The Malta agreement (September 23rd, 2019) is a tentative deal, signed by a group of five EU interior ministers (Germany and France, as well as Finland, Italy and Malta), on a temporary scheme for a rapid relocation in other countries of asylum seekers, who are rescued from the Mediterranean Sea. It could open the way to a comprehensive overhaul of the Dublin Regulation by which the migrant's country of arrival is responsible for verifying the right to asylum of each person. ${ }^{22}$

It states that "the relocation Member State will assume responsibility for the relocated person" and contemplates a quick procedure to say in advance the number of potential refugees each state is willing to host, setting a period of only four weeks to relocate rescued refugees in the Mediterranean in other Member States. This would allow the frontline first-arrival countries (the Mediterranean), to be discharged from the responsibility of participating in their reception, quite heavy in periods of strong migratory pressure. In return, Berlin and Paris hope to achieve a reduction in the socalled "secondary movements" or movements of irregular migrants from the country of entry to other EU states.

\footnotetext{
Aal in Welt am Sonntag. In addition, Aal said that his country already has millions of refugees from nearby countries, such as Syria, Yemen, Iraq or Sudan, so its reception capacity is at the limit.

${ }^{22}$ The EU Ministers discussed on 8-10-19, in Luxembourg this proposal to relocate asylum seekers rescued at sea, but they got a lack of solidarity of the whole European bloc, and the sole support of Portugal, Luxembourg and Ireland.
} 
The agreement also speaks of a return protocol "immediately after landing", redoubling diplomatic pressure on migrant countries of origin, using "appropriate incentives to ensure full cooperation, including consular cooperation, from countries of origin", although at least it includes everyone passing a "medical and safety exam". It also underlines the need to "commit to improving the capabilities of the coastguards of Mediterranean third countries".

It is hoped that the deal will put an end to the game of pass-the-migrant spectacle of some countries squabbling over which should accept responsibility for small numbers of asylum-seekers, breaching in what until now has been a guiding principle: that irregular migrants must be dealt with by their country of first arrival. Since participation in the system will be voluntary, much will now depend on how many countries will take part, how many asylum-seekers each will accept and whether penalties are to be imposed on those countries that refuse to co-operate (this last seems unlikely, given that such an idea would have to be approved by all the EU's members, including the countries liable to be affected (Economist 2019).

Summarizing, there is a widespread perception that a series of instruments to control its external borders are not working well — the Dublin asylum agreements, refugee quotas, Frontex, return and development policies...- and that a lack of trust has grown not only between the Member States, but also between the States and the European institutions, especially after the refugee reception crisis in 2015. In few words, there is a deficient management of migration and a weak European solidarity on this issue (de la Cámara 2019; De Wenden 2019). The call thus is now for a joint cooperation towards a true common policy on asylum and immigration with a complete and efficient control of the EU's external border, reinforcing the role of Frontex. Everybody accepts this priority as the only possibility left for preventing a reinstatement of inner borders controls which would lead to the end of one of the most valued achievements of the EU, the Schengen space.

A positive step in this direction has just being announced, after the starting of their new mandate, by Margaritis Schinas, Vice President of the European Commission in charge of completing a new architecture that guarantees solidarity to the countries of the external border: the EU is going to make sure that there is a sufficient dimension of responsibility in terms of border control and returns. And as tangible measures in that direction, they promise an improvement of the management of external borders with 10,000 permanent staff; moving towards a federalization model of border management, this coming spring there will be the first community corps with their own boats and carry weapons, with the deploying the first 700 European coastguards.

\subsection{Measures in the Countries of Destination}

The responsibility concerning the immigrants does not finish at the border. Once accepted as our guests, we cannot forget about them. And, among our humanitarian obligations, we have to help properly integrating newcomers into our own society, avoiding their eventual fondness towards a multiculturalism, which only produces 
ghettos of their own culture, or wrongly thinking that the mere acceptance as migrants give them the right to have a claim to social welfare.

And, on the contrary, who arrive without being invited cannot impose the host other people's rules. Once they find a home in a new country, they have to accept the laws, rules, traditions and culture of the adopted society that welcomes them, learn the local language, mix with the natives, and be aware of the specific needs and priorities of their new home. In few words, they come to European territory with equal rights and obligations, but no more. Whoever is not able to assimilate to their new society, should better return to their origin (Ramirez 2017, 2019).

According to the Dublin Regulation, asylum-seekers are the responsibility of the first country to record their presence and, if they move later to another European country, this second receptor may return them to the first state, most of them arrive to the southern coasts heading north, trying to slip there unnoticed, as illegal paperless "invisible migrants", to avoid being picked up and returned to their first country of arrival. Officials in the country of arrival can also use bureaucracy to slow the process of registration. And so, after six months, the new host state becomes responsible. This gives a strong incentive for foot-dragging. The recent Malta tentative deal (2019) tries to partially solve this problem, allowing the frontline states to be discharged from the responsibility of participating in the relocation of the newcomers.

Once accepted as our guests, what to do with them? Let us focus on the policy towards them in Sweden and Germany, preferential asylum of most migrants.

Strange enough, they are far from coincident at all.

In Sweden, immigrants received ample food and shelter, a generous welfare benefits, 1.5 times higher than the ones received by host taxpayers, as well as many facilities for family reunification, without any special focus on their social integration. Even more, most of them are not allowed to work. This almost open bar policy, paying migrants to do nothing, has produced (a) an increment of the social expenses on the foreign population, with the consequent reduction of the benefits for the natives -the newcomers have priority to the Swedish people, ${ }^{23}$ (b) a call effect on other tentative immigrants; and (c) increase of criminality and insecurity, which triggers the anti-immigrant feelings of host taxpayers who feel swamped.

In my opinion, migrants should be encouraged to work, getting them language classes and education and offering job training, and introducing them into the labor market, meeting the main demands of the host country: f. ex, in Nordic countries, anticipating a shortfall of geriatric nurses.

In Germany, the arrival of nearly one and a half million asylum seekers since 2015 polarized the country, with a consequent rise of a climate of political anxiety.

\footnotetext{
${ }^{23}$ This also happens in other European countries, like mine. For instance, in Madrid, the benefits and economical public grants for renting a home are higher for migrants than for Spaniards: for each Spaniard that gains access to official protection housing, paid by the taxes of the Spanish residents, are 19 migrants, who have paid nothing for it. Another example: the municipality proposed to regularize illegal unqualified immigrants offering them jobs, forgetting the priority rights of local jobless qualified legal workers (only in the building sector, in Madrid there is a waiting list of 31.000 qualified legal workers), and each illegal migrant gets 550€ monthly, which is more than the $430 €$ many local jobless people get.
} 
It seems they have finally realized that the solution of the problem is to integrate into the labor market those who are already in the country, and relax the requirements to allow the entry of more workers.

With this purpose, in December 2018, the German government approved the Fachkräfteeinwanderungsgesetz ("skilled workers immigration law"), an ambitious legislative package to attract qualified labor from non-EU countries and alleviate the pressing lack of workers in some sectors and regions of the country. This will extend the rules covering foreign graduates to vocationally trained workers, cautiously opening the door for rejected applicants for asylum, but who are already integrated into the labor market, and recruit more workers from outside the EU with medium and high education to find qualified work under certain conditions.

Germany economy enjoys enviable health, registering an unemployment rate of $4.8 \%$, the lowest since the reunification of the country. Figures from the Institute for Employment Research (IAB), under the Ministry of Labor, estimate that there are about 1.2 million jobs vacancies, while posts actually registered in employment offices in November 2018 amounted to 807,000 (35,000 more than the same month of the previous year).

However, one of the biggest concerns of the German businessmen, the so-called Mittelstand, the motor of the exporting power and the backbone of the German economy, is the lack of skilled workers. Unlike in other European countries, small and medium-sized German companies are distributed throughout the country, not necessarily concentrated in industrial centers. This often hinders the recruitment of workers who prefer to live in urban areas. There is a shortage mostly of workers with a level of professional training, such as plumbers, or drivers, and diploma courses, for example, of children's educators. Elderly care and tourism, are also crying out for workers.

This legislative text allows non-EU citizens to go to Germany to seek work for six months provided they have the necessary training, know the language and have the means to survive during that time. In the case of persons with temporary permits, such as rejected asylum seekers, they must show that they have been working in Germany for at least 18 months and that they do not have a criminal record. The head of the employers' association, Ingo Kramer, recently indicated that 400,000 of the asylum seekers who arrived in 2015 are working or receiving some vocational training.

In addition to the labour shortages, there are also demographic forecasts, which warn of a marked aging of the population. These projections will also affect Eastern Europe, where a good part of foreign workers in Germany come from and whose arrival is expected to decrease in the coming years. According to Thomas Liebig, expert on migration issues at the OECD, "these countries are becoming places of immigration. We have to look for workers outside the EU". Although the labor integration of immigrants advances, experts warn that it will take time. "It's a slow process; sometimes they are people who do not speak a word of German, and many of them come from Afghanistan or Somalia, where they have not had schooling" explains Liebig (2018). Tangible achievements, indeed! 
Milanovic and Branco (2018) proposes an intermediate position between open to all or closed borders, under the name of "circular migration": to admit workers who cover specific positions, having salaries and work conditions similar to those of the locals, but with not vote rights, nor social benefits for children, retirement or free education; and at the end of their contracts, they will have to return to their countries. In few words, they will be partial citizens for a limited time, like it is already happening elsewhere: in Gulf, Singapore, Iraq, USA, Canada. Perhaps one country may need extra workers and be in position of offering them stable working conditions; but this may not occur in other EU members. This is also suggested by Alejandro Portes, Princess of Asturias of Social Sciences Award 2019: offering a temporary, flexible and comprehensive program of visas to allow access to young people who want to come to work or study for a while, allowing a fruitful flow between countries. Come in that way would also be much more economical, and would do a lot of damage to the traffickers, because those who come in that way would not have to pay them (17 October 2019).

But, let us close here our considerations, stressing that a revision of national and EU legislation is required, focused towards a cooperation with the countries of origin and transit; and that, instead of dreaming naively in a chimeric -non-existingEuropean Eldorado, we have to promote the great possibilities that African continent has, knowing that, as the journalist Lucia Mbimio says, "we must not stop dreaming, but change the compass of dreams! Returning from Europe to Africa is not a failure." $(2019,66)$.

\section{References}

Alupo BA, Oginni SO, Opoku MP, Torgbenu EL (2019) Psychological experiences of refugees and the response of the community in the Lake Chad region. Behav Sci Terror Polit Aggress 11(3):215-231. https://doi.org/10.1080/19434472.2018.1463552

Aquinas T (1947) Summa theologica (Fathers of the English Dominican Province Translation, Prima Secundae, Question 105, Article 3)

Cole T (2019) Letter to the editor, The Economist

De la Cámara M (2019) The EU migration challenge. Boletín EuroDefense-España 4

De Prada JM (2019) Inmigración y Cuestión Religiosa, ABC, 17 ago

De Ramón-Laca J (2019) Operación Sophia: paradojas de la Acción Exterior Europea. Análisis en 3 minutos I No 228, Agosto 2019

De Wenden CW(2019) A new European pact on immigration and asylum in response to the "migration challenge". European Issues 537, 26th Nov 2019

Dworkin A, Malki F-Z (2018) The southern frontline: EU counter-terrorism cooperation with Tunisia and Morocco. Eur Counc Foreign Relat

Economist (2018) European governments in melt-down over an inoffensive migration compact. The Economist, 6th Dec 2018

Economist (2019a) The problem with EU foreign policy. Too much historical baggage, The Economist, 17th Apr 2019

Economist (2019b) A migrant move in Malta. The EU reaches a tentative deal to share out migrants rescued at sea. The Economist, 24 Sep 2019 
Espaliu C (2018) Taking European defence seriously: the naval operations of the European Union as a model for a Security and Defence Union, Cuadernos europeos de Deusto, pp 157-183

Espaliú Berdud C (2019) Los buques de la Operación Sophia en el dique seco: elementos de un revés para la Política Común de Seguridad y Defensa, Revista de Derecho Comunitario Europeo, vol 64, 2019, pp 829-858. http://www.cepc.gob.es/publicaciones/revistas/revistaselectronicas? $\mathrm{IDR}=4 \& \mathrm{IDN}=1425 \& \mathrm{IDA}=38839$

EU Court of Justice (2015) Decision 2015/1601 of the EU Court of Justice on the application of a system of quotes in the republication of refugees

EU European Parliament (2013) Regulation (EU) No 604/2013 of the European Parliament and of the Council of 26 June 2013. http://www.ipo.gov.ie/en/ipo/pages/eu_dublin_ regulations

Fernández Arriba J (2019) El maridaje perverso entre las mafias libias de tráfico de personas y las ONG, ABC, 8 Sept 2019

Fernández-Sebastián M (2018) Maritime dimension in the fight against illegal migration on the Western Mediterranean route. In: Ramirez JM, Biziewski J (eds) (2019) Security and defence in Europe. Springer, Cham, pp 165-176

Gaceta (2017) Eslovaquia y la reubicación de Refugiados, La Gaceta. https://gaceta.es/europa/ eslovaquia-reubicacion-refugiados-25062017-1659-20170626-0833/. Accessed 26 June 2017

Indelicato M (2019) Sbarchi? Un nuovo schiavismo, Il Giornale.it, 07 Apr 2019

Kurz S (2018) (referred in ABC, 9/9, 2018)

Leguina Joaquín (2019) Migraciones sin respuestas. ABC 10(9):2019

Liebig T (2018) Alemania busca extranjeros para 1, 2 millones de empleos, El País, 20 dic. 2018

Lindhard $\mathrm{T}$ (2018) How to stop migration towards big cities? Research gate. https://www.researchgate.net/post/How_to_stop_migration_towards_big_cities\#view= 5d6388220f95f15c270003d3. Accessed 26 Aug 2018

Mbimio L (2019) Mundo Negro, Madrid, October 2019

Milanovic B (2018) La inevitable migración hacia Europa, El Pais, 18 Nov 18)

Musumeci G, di Nicola A (2016) Confessioni di un trafficante di uomini. Reverse

Niño Elena (2019) Terrorismo e inmigración: cambiando el foco. Artículo 30:2019

Palacio A (2019a) Lazos y nudos con Marruecos, El Mundo, 11 Feb 2019

Palacio A (2019b) Europe's Partnership with Morocco. Proyect Syndicate, 29 Jul 2019

Pellegrini P (2018) Future of Europe. News. European Parliament, 12 Mar 2018

Pius XII (1952) Apostolic constitution Exsul Familia Nazarethana, Castel Gandolfo

Portes A (2019) Princess of Asturias of social sciences award (17 October 2019)

Ramirez JM (2016) Realismo vs. Buenismo ante el Problema de los Refugiados, Migraciones en el siglo XXI: Riesgos y Oportunidades, Comunicaciones, Publicaciones Ministerio de Defensa, pp 309-320

Ramirez, JM (2017). Terrorismo yihadista e Islam. In: Claudio A. Payá \& Fernando Tomé (eds) El Terrorismo como Desafí a la Seguridad Global. Thompson Reuters ARANZADI, pp 211-222

Ramirez JM (2019) The refugees issue in the frame of the European security: a realistic approach. In: Ramirez JM, Biziewski J (eds) Security and defence in Europe. Springer, pp 47-62

Robles P (2019) Bondad y buenismo, ABC, 14 ago

Sarah R (2019) Le soir approche et déjà le jour baisse, Fayard

Sarah R (2019) Interview at Valeurs Actuelles, 5 Apr 2019

Turkish Directorate General of Migration Management (Turkish: Göç İdaresi Genel Müdürlügüü) (2019) Migration Management, 24 Sept 2019

Umar O (2019) Viaje al país de los blancos, Plaza \& Janés

UN Global Compact for Migration (2018) Global compact for safe, orderly and regular migration. Marraquesh, 19 Dec 2018

UNHCR (2017) Global trends: forced displacement in 2017. Accessed from http://www.unhcr.org Zalba Pablo (2014) Reflexiones europeas a mitad de camino. Una visión sobre Europa, EIUNSA, p 2014 
J. Martín Ramírez Chair of the Center for Conflict Studies and Honorary Professor at Nebrija University, Dr. Martin Ramirez is also Fellow of the World Academy of Art and Science and Chair of CICA International Foundation and of the Spanish Pugwash Movement (Peace Nobel Price 1995). He studied Medicine, Humanities, and Law, obtaining a Ph.D. degree in Medicine and Surgery (Neurosciences) and in Philosophy (Education) as well as three Diplomas and a Master in National Defense at the Spanish CESEDEN. Research Fellow of International Security Program of the Harvard University and Visiting Fellow of the Hoover Institution on War, Revolution and Peace, Stanford University. Several times official of the Boarding Council of the International Society for Research on Aggression (ISRA), he is member of the Advisory Board of the Society for Terrorism Research and of the Professors World Peace Academy. He has also chaired the Complutense Research Group on Sociopsychobiology of Aggression and the Departments of Psychobiology at the Seville and Complutense Universities, as well as being Director of the Rector Office at the Autonomous University of Madrid. Dr. Martin Ramirez was a Humboldt and Fullbright Fellow, in Ruhr University and Stanford, respectively, and is author of more than 500 publications, among books and articles. 